\title{
Hydroquinone as the Ring-fission Substrate in the Catabolism of 4-Ethylphenol and 4-Hydroxyacetophenone by Pseudomonas putida JD1
}

\author{
By JACQUELINE M. DARBY, DAVID G. TAYLOR \\ AND DAVID J. HOPPER* \\ Department of Biochemistry and Agricultural Biochemistry, University College of Wales, \\ Aberystwyth, Dyfed SY23 3DD, UK
}

(Received 8 December 1986; revised 2 March 1987)

A bacterium capable of growth on 4-ethylphenol was isolated from soil and identified as Pseudomonas putida. Intact cells grown on 4-ethylphenol rapidly oxidized 4-hydroxyacetophenone as well as growth substrate and the bacterium was also capable of growth on 4-hydroxyacetophenone. The initial enzymes for 4-ethylphenol catabolism were still present, although at lower activities, in succinate-grown cells which oxidized 4-ethylphenol to 4hydroxyacetophenone. Extracts of 4-ethylphenol-grown cells oxidized 4-hydroxyacetophenone when provided with NADPH. When this activity was partially purified a stoichiometry of 1 $\mu \mathrm{mol} \mathrm{O}_{2}$ consumed per $\mu \mathrm{mol}$ of substrate was observed with the production of hydroquinone as required for a monooxygenase producing 4-hydroxyphenyl acetate followed by hydrolysis by an esterase. Cell extracts contained esterase activity and hydrolysed 4-hydroxyphenyl acetate to yield hydroquinone. Intact cells converted the analogue, acetophenone, into phenol. Hydroquinone served as the ring-fission substrate and was cleaved by an $\mathrm{O}_{2}$-requiring reaction. The enzymes of the proposed pathway were induced by growth on 4-ethylphenol or 4hydroxyacetophenone.

\section{INTRODUCTION}

The bacterial metabolism of alkyl-substituted phenols may proceed by initial attack on the alkyl group or, in some cases, the side-chain may be retained intact until after ring fission. This is illustrated by the aerobic pathways that have been described for $p$-cresol metabolism, which include oxidation of the methyl group to carboxyl with eventual formation of protocatechuic acid as ring-fission substrate, or initial hydroxylation of the ring to give 4-methylcatechol which is then cleaved (Dagley \& Patel, 1957; Bayly et al., 1966). Similar possibilities exist for metabolism of the higher homologue, 4-ethylphenol, which, like $p$-cresol, occurs naturally, often as the product of anaerobic conversions of aromatic compounds (Martin, 1982). However, if attack is on the alkyl group very different compounds will be formed and different pathways initiated depending on which of the carbons in the side-chain is oxidized.

The methylene group in the side-chain of 4-ethylphenol is the site for hydroxylation by Pseudomonas putida NCIB 9869, which converts the substrate into 1-(4'-hydroxyphenyl)ethanol and can oxidize this slowly to 4-hydroxyacetophenone (McIntire et al., 1984). The enzyme involved is $p$-cresol methylhydroxylase which has a sufficiently broad specificity to enable it to hydroxylate 4-ethylphenol although the $K_{\mathrm{m}}$ for this substrate is much higher than that for $p$ cresol (McIntire et al., 1985). A notable feature of this enzyme is that it acts by dehydrogenation of the substrate followed by hydration (Hopper, 1978) and will also catalyse the dehydrogenation of the alcohol produced, to give 4-hydroxyacetophenone from 4-ethylphenol. This compound was not metabolized further by $P$. putida NCIB 9869 but a pathway for its metabolism by an Alcaligenes sp. involving 4-hydroxybenzoic acid and protocatechuic acid has been described (Hopper et al., 1985) (pathway 1, Fig. 1). To see if any bacteria use a $p$-cresol methylhydroxylase 
type of enzyme to initiate complete 4-ethylphenol catabolism, several organisms capable of growth on this compound were isolated. The pathway used by one of these, involving attack on the alkyl group and with the uncommon ring-fission substrate, hydroquinone, as intermediate, is described in this paper.

\section{METHODS}

Organism and grow'th. The bacterium, strain JDI, is a short Gram-negative rod, 1-2 $\times 0.7 \mu \mathrm{m}$, with a polar flagellum. It gives a fluorescent green colour when grown on King's B medium and its properties in a range of standard cytological and biochemical tests were in agreement with its identification as a Pseudomonas putida. Bacteria were grown and harvested as described by Hopper et al. (1985). Aromatic carbon sources were at an initial concentration of $0.5 \mathrm{~g} \mathrm{l}^{-1}$ and sodium succinate at $1.0 \mathrm{~g} \mathrm{l}^{-1}$.

Preparation of bacterial extracts. Crude cell extract was prepared by the procedure described previously (Hopper et al., 1985). Where indicated, this was dialysed for $3 \mathrm{~h}$ against 30 vols $42 \mathrm{~mm}$-sodium/potassium phosphate buffer $\mathrm{pH} 7 \cdot 0$, with hourly changes of the buffer.

$D E A E$-cellulose chromatography of crude extract. The 4-hydroxyacetophenone monooxygenase was partially purified by chromatography of crude extract on DEAE-cellulose (DE52). Crude extract (11 ml containing $550 \mathrm{mg}$ protein) was loaded onto a DE52 column $(4.5 \times 2.5 \mathrm{~cm})$ equilibrated with $42 \mathrm{~mm}$-sodium/potassium phosphate buffer $\mathrm{pH} 7 \cdot 0$. It was washed with two column volumes of buffer and then eluted with a linear gradient of $\mathrm{KCl}$ from 0 to $0.3 \mathrm{M}$ in $200 \mathrm{ml}$ buffer. Fractions of $2.8 \mathrm{ml}$ were collected and those containing the enzyme, fractions $2 \mathrm{l}-25$, were pooled.

Chromatography. TLC was done using precoated silica-gel GHLF plates (Analtech) with solvents A [toluene/dioxan/acetic acid $\left(90: 25: 4\right.$, by vol.)], B [light petroleum (b.p. $\left.60-80^{\circ} \mathrm{C}\right) /$ ethyl formate/propionic acid $(70: 30: 15 \cdot 4$, by vol.)] and $C$ [chloroform/methanol $(20: 1, v / v)]$. Aromatic compounds were located by viewing under UV light for materials that quenched the fluorescence of the indicator in the plates. Phenols were located by spraying with Folin-Ciocalteu's phenol reagent followed by exposure to $\mathrm{NH}_{3}$. Ketones were located by spraying with $0.1 \%(\mathrm{w} / \mathrm{v}) 2$,4-dinitrophenylhydrazine in $2 \mathrm{M}-\mathrm{HCl}$.

GLC was performed on a Carlo-Erba HRGC 5300 (Mega Series) instrument using a WCOT fused silica CPWax- 52 CB capillary column $(25 \mathrm{~m} \times 0.32 \mathrm{~mm}$ i.d. $)$. Hydrogen was the carrier gas at a flow rate of $1.5 \mathrm{ml} \mathrm{min}^{-1}$. The temperature programme started at $45^{\circ} \mathrm{C}$ rising to $80^{\circ} \mathrm{C}$ at a rate of $25^{\circ} \mathrm{C} \mathrm{min}-1$ then to $150^{\circ} \mathrm{C}$ at $10^{\circ} \mathrm{C} \mathrm{min}^{-1}$ and finally rising at the maximum rate to $200^{\circ} \mathrm{C}$ where it was held for $10 \mathrm{~min}$.

Spectra. UV absorption spectra were recorded with a Unicam SP8-150 spectrophotometer. IR spectra of samples mulled in Nujol were recorded with a Perkin-Elmer Infracord spectrophotometer.

$\mathrm{O}_{2}$ consumption. Oxidations of substrates by intact cells and cell-free extracts were followed in either a conventional Warburg apparatus or an $\mathrm{O}_{2}$ monitor (Yellow Springs Instrument $\mathrm{Co}$.). For studies with intact cells, Warburg flasks contained $5.0 \mathrm{mg}$ dry wt bacteria in $1.5 \mathrm{ml} 42 \mathrm{mM}$-sodium/potassium phosphate buffer $\mathrm{pH} 7.0,0.3$ $\mathrm{ml} 10 \mathrm{~mm}$-substrate tipped in from the sidearm and $0.2 \mathrm{ml} 20 \%(\mathrm{w} / \mathrm{v}) \mathrm{KOH}$ in the centre well. $\mathrm{O}_{2}$ uptake was measured at $30^{\circ} \mathrm{C}$. In other experiments the intact cells were replaced by cell-free extract and when an NADHgenerating system was required $1 \mu \mathrm{mol} \mathrm{NAD}{ }^{+}, 20 \mu l$ ethanol and $0.1 \mathrm{mg}$ alcohol dehydrogenase ( 35.2 units) were included in the reaction mixture. For an NADPH-generating system $1 \mu \mathrm{mol} \mathrm{NADP}{ }^{+}, 10 \mu \mathrm{mol}$ glucose 6phosphate and 3 units of glucose 6-phosphate dehydrogenase were used.

2,4-Dinitropheny/hydrazones. 2,4-Dinitrophenylhydrazones of reaction products were prepared as described by Cripps et al. (1978).

Assays. 4-Ethylphenol 2'-hydroxylase and 1-(4'-hydroxyphenyl)ethanol dehydrogenase were assayed as described for $p$-cresol methylhydroxylase by McIntire et al. (1985) but with 4-ethylphenol or 1-(4'hydroxyphenyl)ethanol as substrate instead of $p$-cresol.

(4-Hydroxybenzoyl)methanol oxygenase was assayed as described by Hopper \& Elmorsi (1984).

4-Hydroxybenzoate hydroxylase and protocatechuate oxygenase were assayed as described by Hopper et al. (1985). For catechol oxygenase, catechol replaced protocatechuate as substrate.

(4-Hydroxybenzoyl)formate decarboxylase was assayed by measuring $\mathrm{CO}_{2}$ production in the Warburg apparatus as described by Kennedy \& Fewson (1968).

Esterase activity was demonstrated with a pH-stat as described by Norris \& Trudgill (1971) but with 4hydroxyphenylacetate or methyl 4-hydroxybenzoate as substrates instead of $\varepsilon$-hexanolactone and with $4 \mathrm{mg}$ crude extract protein. 4-Hydroxyphenyl acetate hydrolase was assayed spectrophotometrically at $30^{\circ} \mathrm{C}$. The reaction mixture, in a $1 \mathrm{~cm}$ pathlength cuvette, consisted of $3 \mathrm{ml} 42 \mathrm{mM}$-sodium/potassium phosphate buffer $\mathrm{pH} 7 \cdot 0$, containing $2 \mu \mathrm{mol} 4$-hydroxyphenyl acetate. This was made anaerobic by bubbling with $\mathrm{N}_{2}$ and was sealed with a rubber cap. Reaction was started by injection of extract and the increase in $A_{289}$ was followed. An increase of 0.77 was equivalent to production of $1 \mu \mathrm{mol}$ hydroquinone.

4-Hydroxyacetophenone monooxygenase was assayed spectrophotometrically at $30^{\circ} \mathrm{C}$ by following the 
decrease in $A_{3 \rightarrow 0}$ due to oxidation of NADPH. The reaction mixture contained, in $1 \mathrm{ml} 50 \mathrm{~mm}-\mathrm{Tris} / \mathrm{HCl} \mathrm{pH} 8.0$, $0.25 \mu \mathrm{mol}$ NADPH, $1 \mu \mathrm{mol}$ 4-hydroxyacetophenone and extract.

Hydroquinone oxygenase was assayed by following $\mathrm{O}_{2}$ consumption in the $\mathrm{O}_{2}$ monitor at $30^{\circ} \mathrm{C}$. The $3 \mathrm{ml}$ reaction mixture contained $0.1 \mathrm{M}$-sodium/potassium phosphate buffer $\mathrm{pH} 7 \cdot 5,2 \mu \mathrm{mol}$ hydroquinone and cell-free extract.

Attempts to demonstrate various $\mathrm{NAD}^{+-}$or $\mathrm{NADP}^{+}$-linked dehydrogenases spectrophotometrically were made by adding crude extract to $3 \mathrm{ml} 42 \mathrm{~mm}$-sodium/potassium phosphate buffer $\mathrm{pH} 7 \cdot 0$, containing $1 \mu \mathrm{mol}$ of the appropriate substrate and $1 \mu \mathrm{mol} \mathrm{NAD}{ }^{+}$or $\mathrm{NADP}^{+}$in a $1 \mathrm{~cm}$ pathlength cuvette and following the increase in $A_{3+0}$ or $A_{3\urcorner 0}\left(\varepsilon_{370}=2.86 \times 10^{3} \mathrm{M}^{-1} \mathrm{~cm}^{-1}\right)$. Phenol was assayed by incubating $1 \mathrm{ml}$ of sample with $5 \mathrm{ml} 2_{\%}^{\circ}(\mathrm{w} / \mathrm{v})$ $\mathrm{Na}_{2} \mathrm{CO}_{3}$ in $0.1 \mathrm{M}-\mathrm{NaOH}$ and $0.5 \mathrm{ml} 50_{0}^{\circ}$ (v/v) Folin-Ciocalteu's phenol reagent in water, at $30^{\circ} \mathrm{C}$ for $30 \mathrm{~min}$ and then measuring the $A-5_{0}$.

Protein was assayed by the biuret method (Gornall et al., 1949) with bovine serum albumin as standard.

Chemicals. (4-Hydroxybenzoyl)methanol was prepared by the procedure of Robertson \& Robinson (1928). (4Hydroxybenzoyl)formaldehyde was prepared by the $\mathrm{SeO}_{2}$ oxidation of 4-hydroxyacetophenone by following the procedure described by Vogel (1956) for phenylglyoxal preparation from acetophenone. (4-Hydroxybenzoyl)formic acid was prepared by the cold-permanganate oxidation of 4-hydroxyacetophenone. Benzoylmethanol was prepared by treatment of phenacylbromide with acetic acid in triethylamine followed by controlled hydrolysis of the benzoylmethyl acetate produced. Phenyl acetate and methyl benzoate were prepared as described by Vogel (1956). The procedure for phenyl acetate was also used for 4-hydroxyphenyl acetate starting with hydroquinone instead of phenol but with dropwise addition of acetic anhydride to an excess of hydroquinone. Methyl 4hydroxybenzoate, acetophenone, 4-hydroxybenzoic acid, protocatechuic acid, catechol, hydroquinone and 1phenylethanol were from BDH. 4-Ethylphenol, 4-hydroxyacetophenone and 4-hydroxyphenylacetic acid were from Aldrich. 4-Methylcatechol was from R. Emanuel. Homogentisic acid was from Sigma and 1-(4'hydroxyphenyl)ethanol was from NIPA Labs.

\section{RESULTS AND DISCUSSION}

\section{Isolation of bacteria}

Four bacterial strains were isolated from different soil samples by elective culture in liquid medium containing $4 \cdot 1 \mathrm{~mm}$-4-ethylphenol as sole carbon source. These were tested in the $\mathrm{O}_{2}$ monitor for their abilities to oxidize 4-methylcatechol, catechol and protocatechuic acid after growth on 4-ethylphenol. Rapid oxidation of 4-methylcatechol and catechol but not protocatechuic acid was taken as an indication that the probable route for metabolism of 4ethylphenol was by hydroxylation of the ring to give 4-ethylcatechol as the ring-fission substrate. Although this actual intermediate was not tested, catechol 2,3-oxygenases often have a broad specificity (Bayly et al., 1966; Clark \& Slater, 1986) and the 4-ethylcatechol oxygenase might be expected to be active with 4-methylcatechol and catechol. Three of the four strains appeared to use this pathway. The fourth strain, JD1, oxidized 4-methylcatechol only slowly and catechol not at all but there was a slow oxidation of protocatechuic acid. It apparently used a different pathway for catabolism of 4-ethylphenol and was chosen for further study. It was identified as Pseudomonas putida.

\section{Oxidations by intact cells}

4-Ethylphenol grown cells of $P$. putida JDI, in a Warburg apparatus, oxidized both 1-(4'hydroxyphenyl)ethanol and 4-hydroxyacetophenone immediately at rates similar to that for the growth substrate of $3.75 \mu \mathrm{mol} \mathrm{O} \mathrm{O}_{2}^{-1}(\mathrm{mg} \text { dry } \mathrm{wt})^{-1}$ but there was no oxidation of 4hydroxyphenylacetic acid or homogentisic acid. This suggested an initial attack on 4ethylphenol by oxidation of the methylene group of the side-chain rather than the methyl. Protocatechuic acid, a possible ring-fission substrate in the pathway, was oxidized immediately but only slowly at first $\left[0.8 \mu \mathrm{mol} \mathrm{O} \mathrm{O}_{2} \mathrm{~h}^{-1}(\mathrm{mg} \text { dry } \mathrm{wt})^{-1}\right]$ with the rate increasing during the incubation, a pattern typical of enzyme induction.

Lactate- or succinate-grown bacteria also oxidized 4-ethylphenol, although at only about a third of the rate for 4-ethylphenol-grown bacteria and with a lower final consumption approaching only $1 \mu \mathrm{mol} \mathrm{O}_{2}(\mu \mathrm{mol} \text { substrate })^{-1}$, but they did not oxidize 4hydroxyacetophenone. 


\section{Table 1. Specific actitities of enzymes in cell-free extracts}

Crude extracts from 4-ethylphenol-grown (19 $\mathrm{mg}$ protein $\left.\mathrm{ml}^{-1}\right), 4$ hydroxyacetophenone-grown (14.8 $\mathrm{mg}$ protein $\left.\mathrm{ml}^{-1}\right), 4$-hydroxybenzoate-grown $\left(14.3 \mathrm{mg}\right.$ protein $\left.\mathrm{ml}^{-1}\right)$ and succinate-grown $(17 \cdot 2 \mathrm{mg}$ protein $\mathrm{ml}^{-1}$ ) bacteria were assayed as described in Methods. Specific activities are expressed as $\mu \mathrm{mol}$ substrate transformed $\mathrm{min}^{-1}$ (mg protein) ${ }^{-1}$.

\section{Enzyme}

4-Ethylphenol 2'-hydroxylase

1-(4'-Hydroxyphenyl)ethanol dehydrogenase

4-Hydroxyacetophenone monooxygenase

4-Hydroxyphenyl acetate hydrolase

Hydroquinone oxygenase

4-Hydroxybenzoate hydroxylase

Protocatechuate oxygenase

Catechol oxygenase
Specific activity in extracts of bacteria grown on:

$\begin{array}{cccc}\begin{array}{c}\text { 4-Ethyl- } \\ \text { phenol }\end{array} & \begin{array}{c}\text { 4-Hydroxy- } \\ \text { acetophenone }\end{array} & \begin{array}{c}\text { 4-Hydroxy- } \\ \text { benzoate }\end{array} & \text { Succinate } \\ 0.15 & 0.22 & 0.064 & 0.064 \\ 0.083 & 0.055 & 0.05 & 0.034 \\ 0.1 & 0.063 & <0.0001 & <0.0001 \\ 0.15 & 0.28 & 0.0013 & 0.0024 \\ 0.94 & 1.31 & 0.006 & 0.0011 \\ 0.002 & 0.0013 & 0.54 & <0.0001 \\ 0.0086 & 0.0022 & 2.76 & 0.003 \\ <0.0001 & <0.0001 & 0.047 & <0.0001\end{array}$

\section{Product of 4-ethylphenol oxidation by lactate-grown bacteria}

To obtain sufficient product for identification from the limited oxidation of 4-ethylphenol by lactate-grown bacteria, $90 \mu \mathrm{mol}$ substrate was added to a suspension of bacteria ( $168 \mathrm{mg}$ dry wt) in $40 \mathrm{ml} 42 \mathrm{~mm}$-sodium/potassium phosphate buffer $\mathrm{pH} 7 \cdot 0$, in a $100 \mathrm{ml}$ Erlenmeyer flask. This was incubated for $80 \mathrm{~min}$ on an orbital shaker at $30^{\circ} \mathrm{C}$. The bacteria were then removed by centrifuging and the supernatant solution was acidified to $\mathrm{pH} 1$ with $5 \mathrm{M}-\mathrm{HCl}$ and extracted twice with an equal volume of diethyl ether. The combined extracts were dried over anhydrous $\mathrm{Na}_{2} \mathrm{SO}_{4}$ and then evaporated to dryness.

TLC of the product using solvents $A$ and $B$ gave a single spot, when viewed under UV light, corresponding to 4-hydroxyacetophenone $\left(R_{F} 0.54\right.$ and 0.35 in $\mathrm{A}$ and $\mathrm{B}$ respectively) with no trace of starting material $\left(R_{F} 0.7\right.$ and 0.93$)$. Both the product and 4-hydroxyacetophenone gave orange spots when sprayed with 2,4-dinitrophenylhydrazine, which reacts with aldehydes and ketones. The product, crystallized from light petroleum (b.p. $100-120^{\circ} \mathrm{C}$ ), gave UV and IR spectra identical to those for authentic 4-hydroxyacetophenone.

In a similar experiment with 1-(4'-hydroxyphenyl)ethanol as the starting material 4hydroxyacetophenone was again identified as the product. This ketone will also serve as growth substrate for the organism, resulting in the same pattern of enzyme induction as after growth on 4-ethylphenol (Table 1). These results confirm the earlier suggestion that 1-(4'-hydroxyphenyl)ethanol and 4-hydroxyacetophenone are the early intermediates of 4-ethylphenol catabolism.

\section{Activities in extracts}

The oxidation of NADH or NADPH by cell extracts, assayed spectrophotometrically, was not stimulated by addition of 4-ethylphenol as would have been expected for a monooxygenase type of hydroxylase utilizing one of these cofactors. Nor was there evidence, again from spectrophotometric assays, for an $\mathrm{NAD}^{+-}$or NADP+-linked dehydrogenase for 1-(4'hydroxyphenyl)ethanol. However, when extracts were assayed for a p-cresol methylhydroxylasetype of enzyme, which hydroxylates by dehydrogenation followed by hydration, the results were positive with either 4-ethylphenol or 1-(4'-hydroxyphenyl)ethanol as substrate (Table 1). Such an enzyme requires an electron acceptor, which in the assay was phenazine methosulphate. $p$-Cresol methylhydroxylase from $P$. putida NCIB 9869 can oxidize 4-ethylphenol to 4hydroxyacetophenone and it seems likely that a similar enzyme catalyses the first two steps in 4ethylphenol metabolism in $P$. putida JD1.

Hydroxylase was also detected in succinate-grown cells, although at a lower specific activity (Table 1), in agreement with the lower rate of oxidation of 4-ethylphenol seen for intact cells grown on non-aromatic compounds. The stoichiometry of $1 \mu \mathrm{mol} \mathrm{O}_{2}$ required for the conversion of $1 \mu \mathrm{mol}$ 4-ethylphenol into 4-hydroxyacetophenone by the lactate-grown bacteria is also in agreement with the occurrence of two dehydrogenation reactions in the process. 


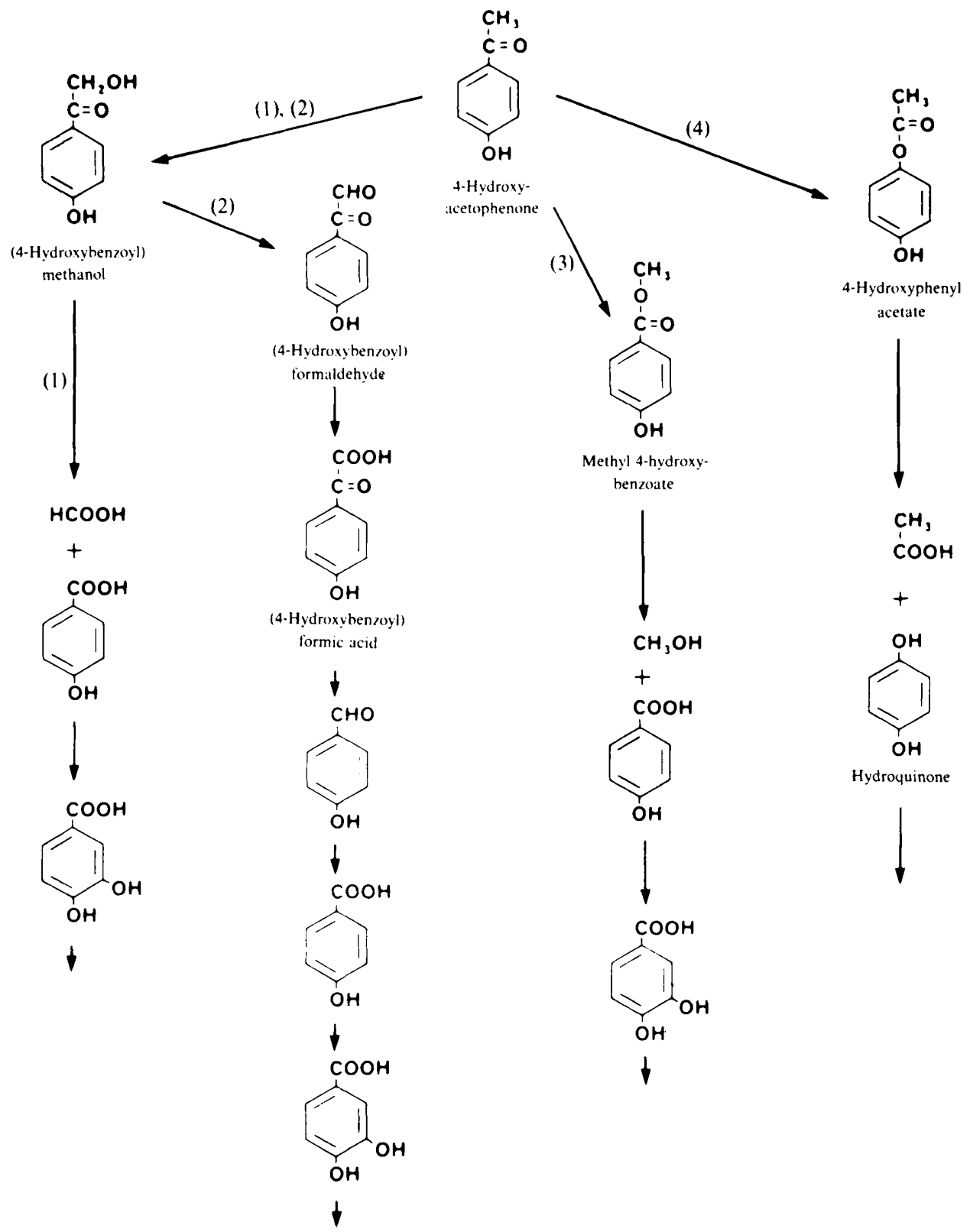

Fig. 1. Some possible pathways for the catabolism of 4-hydroxyacetophenone with a monooxygenasecatalysed first step.

\section{Oxidation of 4-hydroxyacetophenone by cell extracts}

Addition of NADPH to extracts of $P$. putida JDI grown on 4-ethylphenol and 4hydroxyacetophenone, in either the Warburg apparatus or $\mathrm{O}_{2}$ monitor, resulted in consumption of $\mathrm{O}_{2}$, indicative of attack by a monooxygenase. There was no oxidation if NADH replaced NADPH. Some possible pathways for the catabolism of 4-hydroxyacetophenone to ring-fission substrates, in which the first step is catalysed by a monooxygenase, are shown in Fig. 1.

Pathways (1) and (2) involve hydroxylation of the methyl group of 4-hydroxyacetophenone to give (4-hydroxybenzoyl)methanol. Pathway (1) was shown by Hopper et al. (1985) to occur in an 


\section{Table 2. GLC of product from acetophenone oxidation}

The compound isolated after acetophenone oxidation by intact bacteria was identified by comparison of its retention time on GLC with retention times for putative products. GLC was performed as described in Methods.

Compound
Acetophenone
Product
Phenol
Methyl benzoate
Benzoylmethanol
1-Phenylethanol
Phenyl acetate

\section{Compound}

Product

Methyl benzoate

1-Phenylethanol

Phenyl acetate

$\begin{gathered}\text { Retention time } \\ (\mathrm{min})\end{gathered}$
$8 \cdot 2$
$10 \cdot 6$
$10 \cdot 6$
$8 \cdot 05$
$12 \cdot 4$
$8 \cdot 8$
$8 \cdot 0$

Alcaligenes sp. although in this organism NADH was the preferred cofactor for the hydroxylase. Pathway (2) involves complete oxidation of the methyl group to give (4-hydroxybenzoyl)formate, a known intermediate in the catabolism of 4-hydroxymandelic acid, where it undergoes decarboxylation to 4-hydroxybenzaldehyde (Gunter, 1953: Kennedy \& Fewson, 1968). Both of these putative pathways lead to 4-hydroxybenzoic acid with protocatechuic acid as the ringfission substrate, but although intact cells of $P$. putida JDI grown on 4-ethylphenol oxidized both of these compounds the rates were low. Furthermore, when 4-hydroxybenzoate hydroxylase and protocatechuate oxygenase activities were measured in cell extracts, their specific activities in 4ethylphenol- or 4-hydroxyacetophenone-grown bacteria were considerably lower than after growth on 4-hydroxybenzoic acid (Table 1). No (4-hydroxybenzoyl)methanol oxygenase, required for pathway (1), was detected in cell extracts nor was there any (4-hydroxybenzoyl) formate decarboxylase, or $\mathrm{NAD}(\mathbf{P})^{+}$-linked dehydrogenases active with (4-hydroxybenzoyl) methanol or (4-hydroxybenzoyl)formaldehyde, as would be required for pathway (2).

Pathways (3) and (4) both involve the formation of an ester since the first step is catalysed by a monooxygenase that inserts an oxygen atom between two carbons, one of which bears a ketonic group. This type of reaction for the metabolism of ketonic compounds has a number of precedents (Rahim \& Sih, 1966; Forney \& Markovetz, 1969: Norris \& Trudgill, 1971) including the conversion of acetophenone into phenyl acetate (Cripps, 1975; Cripps et al., 1978). Pathway (3) can be ruled out for $P$. putida JDI as it again leads to 4-hydroxybenzoic and protocatechuic acids and, in addition, no esterase activity towards methyl 4-hydroxybenzoate was detected in cell extracts.

\section{Conrersion of acetophenone to phenol by intact cells}

The first indication that pathway (4) (Fig. 1) might be operating came from the isolation and identification of the product from the limited oxidation by intact cells of a substrate analogue, acetophenone. As oxidation was slow, sufficient chloramphenicol was added to inhibit any enzyme synthesis during the incubation. Samples were removed from the incubation mixture at intervals over a period of several hours. Bacteria were removed from each sample by centrifuging and the supernatant solution was extracted twice with an equal volume of diethyl ether. The extracts were dried over anhydrous $\mathrm{Na}_{2} \mathrm{SO}_{4}$ and examined by GLC. The initial peak for acetophenone gradually decreased over the course of the incubation, concomitant with the appearance and increase of a second peak, which had the same retention time as phenol and was clearly separated from other putative products (Table 2 ).

After $6 \mathrm{~h}$ the bacteria were removed from the remainder of the incubation mixture which was then extracted as before. The diethyl ether extract was evaporated to dryness in a test tube and the product was purified by gently heating the bottom of the tube, resulting in evaporation of material and its condensation higher up on the sides of the tube. This material gave a single peak on GLC when mixed with authentic phenol and also gave UV and IR spectra identical with those for phenol. 


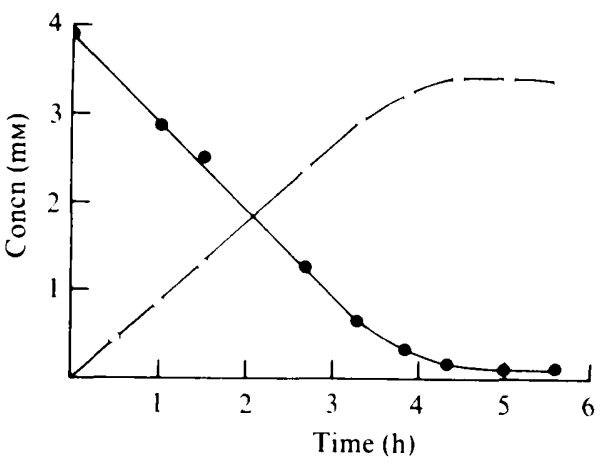

Fig. 2. Conversion of acetophenone into phenol by intact cells. A suspension of 4-ethylphenol-grown $P$. putida JDI (180 mg dry wt) in $100 \mathrm{ml} 42 \mathrm{mM}$-sodium/potassium phosphate buffer $\mathrm{pH} 7 \cdot 0$, containing $50 \mu \mathrm{g}$ chloramphenicol $\mathrm{ml}^{-1}$, in a $250 \mathrm{ml}$ Erlenmeyer flask was incubated on an orbital shaker at $30^{\circ} \mathrm{C}$. An addition of $47 \mathrm{mg}$ acetophenone was made and samples were removed at intervals. Bacteria were removed from samples by centrifuging and the supernatant solutions were assayed for phenol $(O)$ and acetophenone (O)

In a similar experiment. phenol production was followed quantitatively (Fig. 2). Phenol appearance showed good stoichiometry with acetophenone disappearance and it was clearly the major product rather than the result of a minor secondary transformation. This conversion has been described as part of the pathway for acetophenone metabolism in a species of Arthrobacter (Cripps, 1975) where it is catalysed by an ester-forming monooxygenase to give phenyl acetate which is then hydrolysed by an esterase to phenol and acetic acid.

\section{Formation of hydroquinone}

By analogy with this conversion of acetophenone into phenol, 4-hydroxyacetophenone would yield hydroquinone (1,4-dihydroxybenzene) with the intermediate formation of hydroxyphenyl acetate as shown in pathway 4 (Fig. 1). In support of this it was shown that growth of P.putida JDI on either 4-ethylphenol or 4-hydroxyacetophenone resulted in induction of the enzymes 4hydroxyphenyl acetate hydrolase and hydroquinone oxygenase (Table 1).

The presence of the hydroquinone oxygenase precluded the isolation of hydroquinone produced from 4-hydroxyacetophenone by intact cells or crude cell extracts and, therefore, the 4-hydroxyacetophenone monooxygenase was partially purified by chromatography of crude extract on DEAE-cellulose. This preparation was free from hydroquinone oxygenase but still contained esterase activity. A portion was used to oxidize $3 \mu \mathrm{mol} 4$-hydroxyacetophenone in a Warburg apparatus in a reaction mixture containing an excess of NADPH $(5 \mu \mathrm{mol})$. Oxidation ceased after the consumption of $1 \mu \mathrm{mol} \mathrm{O} \mathrm{O}_{2}(\mu \mathrm{mol} \text { substrate })^{-1}$. The flask contents were extracted twice with an equal volume of diethyl ether and the pooled extracts dried over anhydrous $\mathrm{Na}_{2} \mathrm{SO}_{4}$ and then evaporated to dryness. When examined by TLC in solvents $\mathrm{A}$ and $\mathrm{B}$, the product gave a single spot corresponding to hydroquinone $\left(R_{F} 0.41\right.$ and 0.51 in $\mathrm{A}$ and $\mathrm{B}$ respectively). Like hydroquinone it gave a blue colour immediately with Folin-Ciocalteu's phenol reagent, characteristic of a dihydric phenol. There was no trace of starting material ( $R_{F}$ 0.53 and 0.62$)$ or 4-hydroxyphenyl acetate $\left(R_{f} 0.62\right.$ and 0.65$)$, both of which required exposure to $\mathrm{NH}_{3}$ for development of the blue colour, as expected for a monohydroxy phenol.

To demonstrate that hydroquinone was also produced from 4-hydroxyphenyl acetate this substrate was incubated with cell extract under anaerobic conditions to prevent further oxidation of the product by the hydroquinone oxygenase. A Thunberg tube containing $40 \mu \mathrm{mol}$ 4-hydroxyphenyl acetate in $4 \mathrm{ml} 42 \mathrm{~mm}$-sodium/potassium phosphate buffer $\mathrm{pH} 7 \cdot 0$, with $1 \mathrm{ml}$ extract ( $44 \mathrm{mg}$ protein) in the stopper, was alternately evacuated and filled with $\mathrm{N}_{2}$ several times and finally left under vacuum. The cell extract was tipped in and the tube was incubated at $30^{\circ} \mathrm{C}$ 


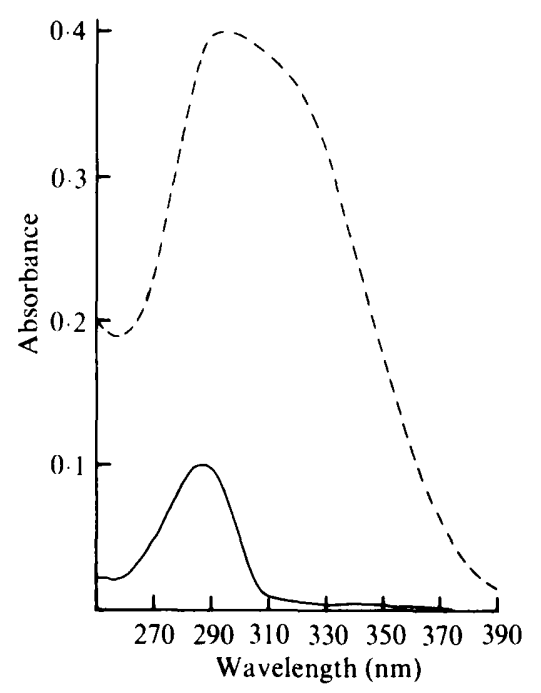

Fig. 3. Spectra of hydroquinone (-) and the product of its oxidation by dialysed crude cell-extract $(--)$. A $1 \mathrm{~cm}$ pathlength cuvette contained $0.1 \mu \mathrm{mol}$ hydroquinone in $3 \mathrm{ml} 42 \mathrm{~mm}$-sodium/ potassium phosphate buffer $\mathrm{pH} 7 \cdot 0$. The spectrum was recorded against a buffer blank; $10 \mu \mathrm{l}$ of dialysed crude extract was added to each cuvette. When there was no further change the spectrum of the product was recorded.

for $30 \mathrm{~min}$. The reaction mixture was then extracted twice with an equal volume of diethyl ether. The combined extracts were dried over anhydrous $\mathrm{Na}_{2} \mathrm{SO}_{4}$, evaporated to dryness and the product examined by TLC in solvents $A$ and $C$. As a control, a second tube with extract that had been heated at $100^{\circ} \mathrm{C}$ for $5 \mathrm{~min}$ was treated in the same way. The product from the first tube gave a single spot on TLC corresponding to the hydroquinone standard when viewed under UV light. Both gave a blue colour when sprayed with Folin-Ciocalteu's phenol reagent before exposure to $\mathrm{NH}_{3}$. There was no trace of starting material which required $\mathrm{NH}_{3}$ before giving a blue colour with the detection reagent. The product from the control tube corresponded to the starting material with only the trace of hydroquinone present as an impurity in the original 4hydroxyphenyl acetate.

\section{Cleavage of hydroquinone}

Crude extract of $P$. putida JDI catalysed rapid oxidation of hydroquinone when assayed in the $\mathrm{O}_{2}$ monitor (Table 1). Oxidation of hydroquinone was also followed spectrophotometrically by repeated scanning of the spectrum when crude extract was added to a cuvette containing hydroquinone. There was a rapid increase in absorbance with a slight shift in $\lambda_{\max }$ to give a spectrum (Fig. 3) similar to that reported by Larway (1965) for the ring-fission product from hydroquinone. This he identified as $\gamma$-hydroxymuconic semialdehyde for which he reported a $\lambda_{\text {max }}$ of $293 \mathrm{~nm}$ at $\mathrm{pH} 7 \cdot 0$.

The requirement for oxygen in the process was demonstrated with a similar reaction mixture made anaerobic by gassing with $\mathrm{O}_{2}$-free argon and sealing the cuvette with a rubber cap. Injection of extract through the cap resulted in very little change in the spectrum but on introduction of $\mathrm{O}_{2}$ there was a rapid increase in absorbance as before. Addition of a small amount of $\mathrm{NAD}^{+}$to the cuvette resulted in complete abolition of the spectrum, and this is in accord with the report by Larway (1965) that the $\gamma$-hydroxymuconic semialdehyde is converted into $\beta$-oxoadipic acid by cell extract in the presence of $\mathrm{NAD}^{+}$. This was confirmed by identifying the product from the oxidation of hydroquinone in the presence of $\mathrm{NAD}^{+} . \mathrm{A}$ reaction mixture containing $5 \mathrm{ml}$ crude extract, $5 \mathrm{ml} 42 \mathrm{mM}$-sodium/potassium phosphate buffer $\mathrm{pH} 7 \cdot 0,5 \mu \mathrm{mol} \mathrm{NAD}^{+}$and $25 \mu \mathrm{mol}$ hydroquinone was incubated with shaking at $30^{\circ} \mathrm{C}$ for 30 min. A small portion of the reaction mixture was then tested for ketones by the Rothera test 


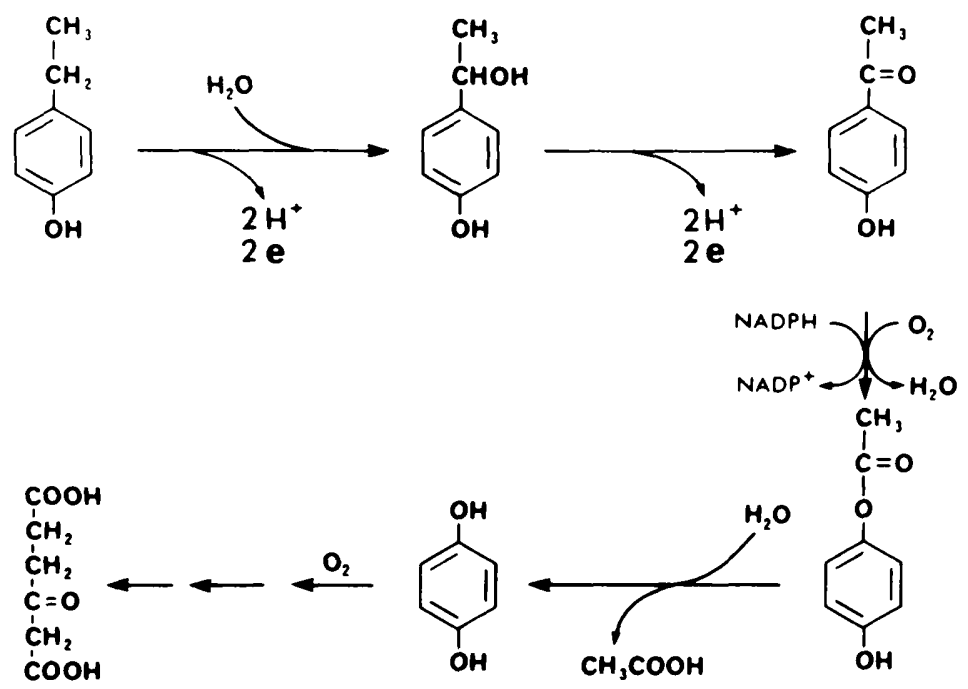

Fig. 4. Proposed pathway for 4-ethylphenol catabolism by P. putida JD1.

(Rothera, 1908) and gave a strong positive reaction. The rest of the reaction mixture was acidified with $5 \mathrm{M}-\mathrm{HCl}$, the protein precipitate removed by centrifuging and the 2,4dinitrophenylhydrazine derivative of the product in the supernatant solution prepared. The 2,4dinitrophenylhydrazone of the product corresponded with that for authentic $\beta$-oxoadipic acid after TLC in solvents $\mathrm{A}$ and $\mathrm{B}\left(R_{F} 0.35\right.$ and 0.64 in $\mathrm{A}$ and $\mathrm{B}$ respectively) and they had identical absorption spectra in neutral and alkaline solution. No 2,4-dinitrophenylhydrazones were extracted from a control reaction mixture without hydroquinone.

\section{Conclusions}

The pathway proposed for 4-ethylphenol catabolism by $P$. putida JDI is shown in Fig. 4. The presence of the relevant enzymes in cell extracts has been demonstrated and their specific activities were increased by growth on 4-ethylphenol over those in bacteria grown on aliphatic compounds (Table 1).

The initial steps appear to be catalysed by a $p$-cresol methylhydroxylase-type of enzyme, but one probably better adapted for substrates with larger side-chains than those previously studied. The specific activities of the enzymes for the first two steps were still at appreciable levels in cells grown on non-aromatic compounds in contrast to those for the rest of the enzymes in the pathway which were barely measurable. This allowed sufficient accumulation of 4hydroxyacetophenone to itentify it as the product of oxidation of 4-ethylphenol.

The metabolism of 4-hydroxyacetophenone by this organism was via a different pathway from that used by an Alcaligenes sp. (Hopper et al., 1985) and paralleled the route described by Cripps (1975) for acetophenone catabolism, resulting in formation of hydroquinone rather than phenol. Indeed, the outline of the pathway was established because the enzymes for 4-hydroxyacetophenone breakdown were of sufficiently broad specificity to convert acetophenone into phenol.

One of the unusual features of this pathway is the occurrence of hydroquinone as the ringfission substrate. Reports abound of other dihydric phenols serving as ring-fission substrates in the metabolism of aromatic compounds (Dagley, 1975). Catechol and protocatechuic acid are found as the final aromatic intermediates in pathways for a range of different benzenoid compounds and similarly the $p$-dihydric phenol, gentisic acid, and its homologues are wellestablished ring-fission substrates (Chapman, 1972). Oxidative cleavage of these intermediates and subsequent breakdown to central metabolites have been thoroughly studied and are well understood. In contrast there have been relatively few reports of hydroquinone in this role. 
Those that have appeared include its cleavage by a bacterium growing on hydroquinone itself (Larway, 1965; Larway \& Evans, 1965) and identification as an intermediate in the catabolism of p-nitrophenol by a Moraxella sp. (Spain et al., 1979). To these can now be added its role as the ring-fission substrate in the catabolism of 4-ethylphenol and 4-hydroxyacetophenone. The pathway for metabolism of hydroquinone to central metabolites has never been described in detail although Larway (1965) identified $\gamma$-hydroxymuconic semialdehyde as the product of ringfission and showed its conversion into $\beta$-oxoadipic acid by cell extracts. The results described for hydroquinone oxidation by $P$. putida JDI are in agreement with this but the details have still to be elucidated.

\section{REFERENCES}

Bayly, R. C., Dagley, S. \& Gibson, D. T. (1966). The metabolism of cresols by species of Pseudomonas. Biochemical Journal 101, 293-301.

Chapman, P. J. An outline of reaction sequences used for the bacterial degradation of phenolic compounds. In Degradation of Synthetic Organic Molecules in the Biosphere, pp. 17-55. Edited by P. J. Chapman \& S. Dagley. Washington DC: Printing and Publishing Office, National Academy of Sciences.

Clarke, P. H. \& Slater, J. H. (1986). Evolution of enzyme structure and function. In The Bacteria, vol. X, p. 99. Edited by J. R. Sokatch \& L. N. Ornston. London: Academic Press.

CRIPPS, R. E. (1975). The microbial metabolism of acetophenone and some chloroacetophenones by an Arthrohacter species. Biochemical Journal 152, 233241.

Cripps, R. E., Trudgill, P. W. \& Whateley, J. G. (1978). The metabolism of 1-phenylethanol and acetophenone by Nocardia T5 and an Arthrohacter species. European Journal of Biochemistry 86. 175 186.

DAGLEY, S. (1975). A biochemical approach to some problems of environmental pollution. In Essays in Biochemistry, vol. II. pp. 81-138. Edited by P. N. Campbell \& W. N. Aldridge. London: Academic Press.

DAGley, S. \& Patel, M. D. (1957). Oxidation of pcresol and related compounds by a Pseudomonas. Biochemical Journal 66, 227-233.

Forney, F. W. \& Markovetz, A. J. (1969). An enzyme system for aliphatic methyl ketone oxidation. Biochemical and Biophysical Research Communications 37, 31-38.

GUNTER, S. E. (1953). The enzymatic oxidation of $p$ hydroxymandelic acid to $p$-hydroxybenzoic acid Journal of Bacteriology 66, 341-346.

Gornall, A. G., Bardawill, C. J. \& David, M. M. (1949). Determination of serum proteins by means of the biuret reaction. Journal of Biological Chemistry 177, 751-766.

HOPPER, D. J. (1978). Incorporation of $\left[{ }^{18} \mathrm{O}\right]$ water in the formation of $p$-hydroxybenzyl alcohol by the $p$ cresol methylhydroxylase from Pseudomonas putida. Biochemical Journal 175, 345-347.

Hopper, D. J. \& Elmorsi, E. A. (1984). Cleavage of formate from $\omega, 4$-dihydroxyacetophenone. An un- usual oxygen-requiring reaction in the bacterial catabolism of 4-hydroxyacetophenone. Biochemical Journal 218, 269-272.

Hopper, D. J., Jones, H. G., Elmorsi, E. A. \& RHODES-ROBERTS, M. E. (1985). The catabolism of 4hydroxyacetophenone by an Alcaligenes sp. Journal of General Microbiolog! 131, 1807-1814.

KENNEDY, S. I. T. \& FEWSON, C. A. (1968). Enzymes of the mandelate pathway in bacterium NCIB 8250 . Biochemical Journal 107, 497-506.

LARWAY, P. F. (1965). The oxidative metabolism of certain phenols by microorganisms, PhD. thesis, University College of North Wales, Bangor.

LARWAY, P. F. \& EVANS, W. C. (1965). Metabolism of quinol and resorcinol by soil pseudomonads. Biochemical Journal 95, 52P.

MARTIN, A. K. (1982). The origin of urinary aromatic compounds excreted by ruminants. 3 . The metabolism of phenolic compounds to simple phenols. British Journal of Nutrition 48, 497-507.

Mcintire, W., Hopper, D. J., Craig, J. C., Everhart. E. T., Webster, R. V., Causer, M. J. \& Singer, T. P. (1984). Stereochemistry of 1-(4'hydroxyphenyl)ethanol produced by hydroxylation of 4-ethylphenol by $p$-cresol methylhydroxylase. Biochemical Journal 224, 617-621.

MCIntire, W.. Hopper, D. J. \& Singer, T. P. (1985). $p$-Cresol methylhydroxylase: assay and general properties. Biochemical Journal 228, 325-335.

Norris, D. B. \& Trudgill, P. W. (1971). The metabolism of cyclohexanol by Nocardia gloharula CL1. Biochemical Journal 121, 363-370.

Rahim. M. A. \& SiH, C. J. (1966). Mechanisms of steroid oxidation by microorganisms. XI Enzymatic cleavage of the pregnane side chain. Journal of Biological Chemistry 241. 3615-3623.

Robertson, A. \& Robinson, R. (1928). Experiments on the synthesis of anthrocyanins. Journal of the Chemical Society, 1460-1472.

Rothera, A. C. H. (1908). Note on the sodium nitroprusside reaction for acetone. Journal of Phy:siology 37, 491-494.

Spain, J. C., Wyss, O. \& Gibson, D. T. (1979). Enzymatic oxidation of p-nitrophenol. Biochemical and Biophysical Research Communications 88, 634 641 .

Vogel, A. I. (1956). Practical Organic Chemistry, 3rd edn. London: Longman, Green. 